\title{
PERTUMBUHAN TANAMAN JARAK PAGAR (Jatropha curcas L.) PADA LAHAN PASCA TAMBANG TIMAH DI BANGKA YANG DIBERI PUPUK ORGANIK
}

\author{
Sukmarayu P. Gedoan ${ }^{1)}$, Alex Hartana ${ }^{2)}$, Hamim $^{2)}$, Utut Widyastuti ${ }^{2)}$ \\ dan Nampiah Sukarno ${ }^{2)}$ \\ ${ }^{1)}$ Program Studi Biologi, FMIPA Universitas Negeri Manado di Tondano \\ ${ }^{2)}$ Departemen Biologi, FMIPA, Institut Pertanian Bogor, Bogor 16680
}

\begin{abstract}
ABSTRAK
Kegiatan penambangan timah menyebabkan perubahan karakteristik fisika dan kimia tanah sehingga menjadi tidak sesuai untuk pertumbuhan tanaman. Tujuan penelitian ini untuk mempelajari pertumbuhan 7 aksesi jarak pagar yang ditanam pada lahan pasca tambang timah yang diberi kompos dan kotoran sapi. Penelitian ini dilakukan di TSS 133, Kelurahan Sinar Baru, Kabupaten Bangka, Provinsi Bangka Belitung. Penelitian lapangan dilaksanakan pada Bulan Mei 2007 sampai dengan Bulan Desember 2008. Percobaan faktorial ini dirancang dalam Rancangan Petak Terbagi dengan tiga ulangan. Petak utama adalah 7 aksesi jarak pagar yang terdiri atas: aksesi Madiun, Ponorogo, Jember, Dompu, Lampung, Bengkulu, dan Sukabumi, sedangkan anak petak berupa tanah tanpa pemberian kompos dan pupuk kandang (kontrol), kompos trubus 4 $\mathrm{kg} / \mathrm{lubang}$ ditambah $4 \mathrm{~kg}$ tanah bagian atas dan kotoran sapi $4 \mathrm{~kg} / \mathrm{lubang}$ ditambah $4 \mathrm{~kg}$ tanah bagian atas. Hasil penelitian menunjukkan bahwa pertumbuhan awal yang paling baik untuk tanah bekas tambang timah adalah pada aksesi Jember yang ditunjukkan oleh diameter batang, berat kering tanaman, berat kering tajuk dan berat kering akar. Sedangkan tinggi tanaman tertinggi diamati pada aksesi Madiun. Penambahan kotoran sapi dapat meningkatkan produksi biji dan kandungan minyak. Produksi biji tertinggi diperoleh pada aksesi Bengkulu dan kandungan minyak tertinggi diperoleh pada aksesi Dompu.
\end{abstract}

Kata kunci: aksesi, Jatropha curcas, kompos, kotoran sapi

\section{THE GROWTH OF CASTOR OIL PLANT (Jatropha curcas L.) ON THE POST- TIN-MINING LAND IN BANGKA PROVIDED WITH ORGANIC FERTILIZER}

\begin{abstract}
The activity of tin mining changes the physical and chemical characteritics of soil, so that the soil isnot suitable for plant growth. The objective of this research was to evaluate the growth of some accession of Jatropha curcas that we planted on post-tin-mining land provided with compost and cow feces. This research was conducted in TS 133, Sinar Baru Village, District of Bangka, Province of Bangka Belitung. This field research was carried out in May 2007 to December 2008. Factorial experiment was designed as split plot with three replications. The main plot was 7 accessions, i.e. Madiun, Ponorogo, Jember, Dompu, Lampung, Bengkulu, and Sukabumi. The subplot waskonds of organic fertilizer, i.e. top soil without addition of compost and cow fecer (control), trubus compost (4 kg/hole) added with top soil (4 kg/hole), and cow feces $(4 \mathrm{~kg} / \mathrm{hole})$ added with topbsoil $(4 \mathrm{~kg} / \mathrm{hole})$. The result showed that Jember accession had the best early growth based on the observation of stem diameter, plant dry weight, and root dry weight. The largest plant height was observed in Madiun accession. The higest seed production was observed in Bengkulu accession and Dompu accession had the higest oil content.
\end{abstract}

Keywords: accession, Jatropha curcas, , compost, cow feces

\section{PENDAHULUAN}

Pulau Bangka merupakan salah satu penghasil timah di Indonesia yang memulai penambangan timah sekitar abad ke-18 (Sujitno, 2007). Penambangan timah berlanjut sampai sekarang baik yang dilakukan oleh PT Timah, PT Coba Tin 
maupun oleh masyarakat berupa tambang inkonvensional.

Dampak kegiatan penambangan timah pada lingkungan hidup adalah perubahan drastis atas sifat fisika tanah dan sifat kimia tanah khususnya di sekitar lokasi tambang bersangkutan. Pengaruh pada sifat fisik tanah tampak pada perubahan tekstur dan morfologi tanah akibat penggalian tanah bagian atas (top soil) untuk mencapai lapisan bertimah yang lebih dalam (Sujitno, 2007). Tanah bekas penambangan berupa hamparan tailing pasir mengandung fraksi pasir lebih dari 94\%, fraksi liat kurang dari 3\%, kandungan bahan organik kurang dari 1,78\% berupa C-organik, daya cengkeram air sangat rendah, daya permeabilitas air sangat cepat, jumlah bakteri dan jamur sangat rendah.

Salah satu tanaman potensial yang diharapkan dapat beradaptasi dengan cepat di lahan bekas tambang timah adalah jarak pagar. Sebagai salah satu tanaman pionir jarak pagar mempunyai potensi kandungan minyak tinggi, yang dapat dimanfaatkan sebagai tanaman penghasil minyak alternatif untuk subtitusi solar sebagai biodiesel.

Tanaman jarak pagar bisa beradaptasi pada lahan marginal atau lahan kritis yang secara fisik dan kimia sangat miskin. Namun untuk mendapatkan pertumbuhan jarak pagar yang baik seperti penampilan morfologi dan aspek pertumbuhan yang menunjang produksi biji dan kandungan minyak yang tinggi diperlukan perlakuan tertentu. Perlakukan itu berupa bahan organik seperti kompos dan pupuk kandang, dolomit atau pembuatan pot dalam tanah yang berisi tanah bagian atas (top soil).

Selain itu bahan tanaman jarak pagar yang digunakan sebaiknya memiliki keunggulan genetik yang dicirikan oleh potensi produksi biji tinggi, cepat berproduksi (berumur genjah) dan beradaptasi luas terhadap lingkungan yang tidak menguntungkan (Hasnam dan Mahmud, 2006). Hasil minyak per tanaman ditentukan oleh jumlah biji per tangkai atau per tanaman, berat biji, dan konsentrasi minyak yang ketiganya dipengaruhi oleh faktor genetik dan masih dapat dimodifikasi oleh lingkungan (Leon et al., 2003).

Untuk mengembalikan fungsi lahan bekas penambangan timah diusahakan berbagai cara seperti penggunaan tanah bagian atas (top soil) pada media tanam, bahan organik berupa kompos dan pupuk kandang. Penggunaan bahan organik diharapkan dapat meningkatkan serapan hara tanaman jarak pagar. Pupuk kandang berperan sebagai sumber dan penambah unsur hara, mempertinggi humus, memperbaiki struktur tanah, dan meningkatkan kehidupan biota tanah. Oleh karena itu diharapkan penelitian ini dapat memberikan informasi penampilan tanaman jarak pagar yang bisa beradaptasi pada lahan bekas tambang timah yang diberikan bahan organik berupa kompos dan kotoran sapi.

Tujuan penelitian ini untuk mempelajari 7 aksesi jarak pagar yang ditanam pada lahan pasca tambang timah yang diberi kompos dan kotoran sapi.

\section{METODOLOGI PENELITIAN}

\section{Tempat dan Waktu Penelitian}

Penelitian ini dilakukan di TS 133 kelurahan Sinar Baru, Kabupaten Bangka, Provinsi Bangka Belitung untuk penelitian lapangan. Pengukuran berat kering tajuk dan akar dilakukan di Laboratorium Fisiologi Tumbuhan Departemen Biologi, FMIPA, IPB. Analisis kadar N, P dan K dilakukan di Balai Penelitian Tanah, Badan Penelitian dan Pengembangan Pertanian, Departemen Pertanian. Analisis kandungan minyak dilakukan di Laboratorium Mutu dan Keamanan Pangan 1, SEAFAST CENTER, IPB, Bogor. Penelitian dilaksanakan bulan Mei 2007 sampai dengan Desember 2008.

\section{Metode Penelitian}

Penelitian ini berupa percobaan faktorial yang dirancang dalam Rancangan Petak Terbagi. Sebagai petak utama adalah 7 aksesi jarak pagar yang terdiri atas : aksesi Madiun, Ponorogo, Jember, Dompu, Lampung, Bengkulu, dan Sukabumi, sedangkan anak petak berupa tanah tanpa pemberian kompos dan pupuk kandang (kontrol), kompos trubus $4 \mathrm{~kg} / \mathrm{lubang}$ ditambah $4 \mathrm{~kg}$ tanah bagian atas (top soil) dan kotoran sapi $4 \mathrm{~kg} / \mathrm{lubang}$ ditambah $4 \mathrm{~kg}$ tanah bagian atas (top soil). Setiap satuan percobaan terdapat 4 tanaman per petak.

Sebelum tanaman ditanam maka bahan organik dimasukkan dalam setiap lubang tanaman satu minggu sebelum penanaman. Kompos trubus dan kotoran sapi yang diberikan dicampur merata dengan 
tanah bagian atas (top soil) kemudian dimasukkan dalam tiap lubang tanam. Lubang tanam yang telah diinkubasi selama satu minggu kemudian ditanami dengan jarak pagar.

Peubah tanaman yang diamati : tinggi tanaman, diameter batang, jumlah cabang, berat kering tanaman, berat kering tajuk, dan berat kering akar pada umur 8 bulan setelah tanam (BST), produksi biji berupa berat biji total sampai tanaman berumur 12 bulan setelah tanaman, dan analisis kandungan minyak dilakukan dengan metode AOAC (1990). Analisis kadar N, P, dan $\mathrm{K}$ dilakukan pada umur 6 bulan setelah tanam. Analisis kadar $\mathrm{N}$ dilakukan dengan menggunakan Kjeldahl. Analisis kadar P dilakukan dengan menggunakan Metode dari Watanabe dan Olsen (1965), menggunakan Atomic Absorption Spectophotometer (AAS). Analisis kadar $\mathrm{K}$ dilakukan dengan menggunakan Atomic Absorbance Spectroscopy.

\section{Analisis Data}

Data dianalisis dengan Analisis Varians menggunakan program SAS 9.1 for Windows dan dilanjutkan dengan pengujian menggunakan Uji Perbandingan Berganda Duncan (UPBD).

\section{HASIL DAN PEMBAHASAN}

\section{Karakteristik Sifat Fisik, Kimia, dan Kadar Logam Berat}

Dampak aktivitas penambangan timah di pulau Bangka adalah perubahan drastis atas sifat fisika tanah dan sifat kimia tanah, khususnya di sekitar lokasi tambang bersangkutan (Sujitno, 2007). Kondisi tanah asal yang sudah miskin hara akan semakin rusak dengan kegiatan pertambangan. Berdasarkan data yang diperoleh dari lahan bekas tambang timah TS 1.33, Propinsi Bangka Belitung telah terjadi kerusakan horizon tanah dan juga struktur tanah asal, kandungan hara dari tailing yang diuji juga tergolong rendah baik bahan organik, hara makro maupun hara mikronya (PT. Tambang Timah 1991).

Keadaan tanah sebelum ditanami dengan jarak pagar mempunyai tekstur pasir dengan kadar pasir $83 \%$, liat $13 \%$, dan debu $4 \%$ (Tabel 1). Keadaan tekstur tanah di atas sudah mengalami perubahan terutama terjadi penurunan kadar pasir, kadar liat, dan kadar debu yang tinggi dibandingkan dengan tekstur tanah pada beberapa tingkat umur tailing (Sitorus et al., 2008).

Unsur hara makro tergolong sangat rendah yaitu $\mathrm{N} 0.02 \%$, $\mathrm{P} 15$ ppm, dan $\mathrm{K} 46$ $\mathrm{ppm}$. Unsur hara $\mathrm{P}$, dan $\mathrm{K}$ termasuk tinggi bila dibandingkan dengan $\mathrm{P}$ dengan kisaran $1.4 \mathrm{ppm}$ pada umur tailing 0 tahun sampai 3.9 ppm pada umur tailing 16 tahun, demikian pula untuk $\mathrm{K}$ lebih tinggi dibandingkan dengan $\mathrm{K}$ pada umur tailing 0 tahun (Sitorus et al., 2008).

Keasaman tanah sebesar 5.6, yang biasanya nilai $\mathrm{pH}$ tanah di Bangka rata-rata di bawah 5 (BPS, 2001). Proses aktivitas penambangan berpengaruh nyata menurunkan $\mathrm{pH}$ tanah (Amriwansyah, 1990), namun terjadi peningkatan $\mathrm{pH}$ pada tanah bekas tambang timah berumur 25 tahun.

Tabel 1 Karakteristik sifat fisik, kimia dan kadar logam berat dari lokasi TS 133

\begin{tabular}{|c|c|c|c|c|c|}
\hline \multicolumn{2}{|c|}{ Sifat Fisik } & \multicolumn{2}{|c|}{ Sifat Kimia } & \multicolumn{2}{|c|}{ Kadar logam berat (ppm) } \\
\hline Kadar pasir (\%) & 83 & $\mathrm{pH}$ & 5.6 & $\mathrm{Fe}$ & 286 \\
\hline $\begin{array}{l}\text { Kadar debu (\%) } \\
\text { Kadar liat (\%) }\end{array}$ & $\begin{array}{c}4 \\
13\end{array}$ & $\begin{array}{l}\text { Kadar } \mathrm{N} \text { total }(\%) \\
\mathrm{P} \text { tersedia }(\mathrm{ppm})\end{array}$ & $\begin{array}{c}0.02 \\
15\end{array}$ & $\begin{array}{l}\mathrm{Al} \\
\mathrm{Mn}\end{array}$ & $\begin{array}{c}1852 \\
1.4\end{array}$ \\
\hline Kelas tekstur & pasir & $\begin{array}{l}\mathrm{K} \text { tersedia }(\mathrm{ppm}) \\
\mathrm{Ca}-\mathrm{dd}(\mathrm{cmol}(+) / \mathrm{kg} \\
\mathrm{Mg}-\mathrm{dd}(\mathrm{cmol}(+) / \mathrm{kg} \\
\mathrm{Na}-\mathrm{dd}(\mathrm{cmol}(+) / \mathrm{kg} \\
\mathrm{S}(\mathrm{ppm})\end{array}$ & $\begin{array}{c}46 \\
2 \\
6 \\
15 \\
107\end{array}$ & $\begin{array}{l}\mathrm{Zn} \\
\mathrm{Pb} \\
\mathrm{Ni} \\
\mathrm{Cr} \\
\mathrm{Sn}\end{array}$ & $\begin{array}{c}4.9 \\
7.7 \\
70 \\
4 \\
7.2\end{array}$ \\
\hline & & & & Mo & 0.9 \\
\hline
\end{tabular}




\section{Pertumbuhan, Produksi Biji, dan Kandungan Minyak Jarak Pagar}

Penelitian yang dilakukan menggunakan bahan organik berupa kompos trubus dan kotoran sapi dengan kontrol tanpa menggunakan bahan organik. Karakter pertumbuhan vegetatif yang diamati adalah tinggi tanaman, diameter batang dan jumlah cabang yang dilakukan pada umur delapan bulan setelah tanam (Tabel 2). Terdapat interaksi antara bahan organik dengan aksesi terhadap tinggi tanaman sedangkan diameter batang tidak terdapat interaksi antara ke dua faktor tersebut.

Pengaruh penambahan kompos trubus terhadap tinggi tanaman dan diameter batang memperlihatkan perbedaan pola. Tinggi tanaman yang meningkat dua kali diikuti oleh diameter batang hampir dua kali pada aksesi Madiun, Lampung, dan Bengkulu dibandingkan tanpa pemberian bahan organik. Aksesi Jember dan Sukabumi, pertambahan tinggi tanaman meningkat tiga kali tetapi pertambahan diameter batang sama dengan aksesi Madiun, Lampung, dan Bengkulu, apabila dibandingkan dengan tanpa penambahan bahan organik. Namun pada aksesi Ponorogo, pertumbuhan tinggi tanaman kurang dari dua kali diikuti oleh pertambahan diameter batang dua kali sedangkan aksesi Dompu tinggi tanaman meningkat lebih dari dua kali diikuti pertambahan diameter batang lebih dari dua kali juga dibandingkan dengan tanpa penambahan bahan organik.

Respon tinggi tanaman dan diameter batang terhadap penambahan kotoran sapi dibandingkan dengan tanpa penambahan bahan organik dikelompokkan dalam lima kelompok. Kelompok pertama adalah aksesi Madiun, tinggi tanaman yang meningkat lebih dari tiga kali diikuti dengan pertambahan diameter batang hampir dua kali. Kelompok kedua tinggi tanaman meningkat dua kali dengan pertambahan diameter lebih dari dua kali pada aksesi Ponorogo. Kelompok ketiga tinggi tanaman yang meningkat tiga kali diikuti pertambahan diameter batang lebih dari dua kali pada aksesi Jember, dan Sukabumi. Kelompok keempat, aksesi Dompu dan Lampung tinggi tanaman meningkat lebih dari dua kali dengan pertambahan diameter lebih dari dua kali juga. Kelompok kelima aksesi Bengkulu, pertumbuhan tinggi tanaman lebih dari dua kali dengan diameter batang bertambah dua kali. Penambahan kotoran sapi memberikan tinggi tanaman yang tertinggi yaitu pada aksesi Madiun sedangkan diameter yang terbesar pada aksesi Jember. Tinggi tanaman yang semakin tinggi tidak diikuti dengan pertambahan diameter batang.

Tabel 2 Tinggi tanaman dan diameter batang umur 8 BST

\begin{tabular}{|c|c|c|c|c|c|c|c|c|}
\hline \multirow[t]{2}{*}{$\begin{array}{l}\text { Bahan } \\
\text { organik }\end{array}$} & \multicolumn{8}{|c|}{ Aksesi } \\
\hline & AM & $\overline{\mathrm{AP}}$ & $\mathrm{AJ}$ & $\mathrm{AD}$ & $\mathrm{AL}$ & $\mathrm{AB}$ & AS & Rerata \\
\hline $\begin{array}{l}\text { B0 } \\
\text { B1 } \\
\text { B2 } \\
\end{array}$ & $\begin{array}{r}28.4^{\mathrm{f}} \\
60.9^{\text {cd }} \\
99.6^{\mathrm{a}} \\
\end{array}$ & $\begin{array}{c}25.8^{\mathrm{f}} \\
47.7^{\mathrm{de}} \\
65.8^{\mathrm{cd}}\end{array}$ & $\begin{array}{r}\mathrm{Ti} \\
24.5^{\mathrm{f}} \\
76.6^{\mathrm{bc}} \\
90.6^{\mathrm{ab}}\end{array}$ & $\begin{array}{c}\text { i tanam } \\
29.3^{\mathrm{f}} \\
77^{\mathrm{bc}} \\
79.8^{\mathrm{bc}}\end{array}$ & $\begin{array}{l}(\mathrm{cm}) \\
27.6^{\mathrm{f}} \\
59.4^{\mathrm{cd}} \\
75.1^{\mathrm{bc}}\end{array}$ & $\begin{array}{l}31.7^{\mathrm{ef}} \\
66.7^{\mathrm{cd}} \\
72.4^{\mathrm{bc}}\end{array}$ & $\begin{array}{l}25.1^{\mathrm{f}} \\
78.9^{\mathrm{bc}} \\
92.3^{\mathrm{ab}}\end{array}$ & \\
\hline \multicolumn{9}{|c|}{ Diameter batang $(\mathrm{cm})$} \\
\hline B0 & 1.64 & 1.47 & 1.62 & 1.48 & $1, .61$ & 1.54 & 1.46 & $1.54^{\mathrm{c}}$ \\
\hline B1 & 3.16 & 2.94 & 3.04 & 3.19 & 2.95 & 2.61 & 2.87 & $2.97^{\mathrm{b}}$ \\
\hline B2 & 3.21 & 3.05 & 3.32 & 3.24 & 3.31 & 3.08 & 3.09 & $3.19^{\mathrm{a}}$ \\
\hline Rerata & $2.67^{\mathrm{a}}$ & $2.49^{\mathrm{b}}$ & $2.66^{\mathrm{a}}$ & $2.64^{\mathrm{a}}$ & $3.13^{\mathrm{a}}$ & $2.41^{\mathrm{b}}$ & $2.47^{\mathrm{b}}$ & \\
\hline
\end{tabular}

Keterangan : AM:aksesi Madiun, AP:aksesi Ponorogo, AJ:aksesi Jember, AD:aksesi Dompu, AL:aksesi Lampung, AB:aksesi Bengkulu, AS:aksesi Sukabumi, B0:tanpa penambahan bahan organik, B1:penambahan kompos trubus, B2:penambahan kotoran sapi. Angka yang diikuti huruf yang sama tidak berbeda nyata menurut UPBD 5\%.

Pola pertambahan tinggi tanaman dan diameter batang berbeda dengan pola pembentukan cabang. Faktor aksesi dan bahan organik tidak berpengaruh nyata 
terhadap jumlah cabang (Tabel 3). Tanpa pemberian bahan organik jumlah cabang yang terbentuk bervariasi jumlahnya mulai tidak terbentuk cabang sampai empat cabang. Tanpa penambahan bahan organik jumlah cabang pada aksesi Dompu dan Lampung lebih banyak, tetapi jumlah cabang yang terbentuk pada kedua aksesi itu kecil dan pendek. Pada aksesi Jember walaupun ratarata tinggi tanaman sebesar $24.5 \mathrm{~cm}$ dan diameter batang $1.62 \mathrm{~cm}$ tetapi tidak terbentuk cabang.

Pada aksesi Madiun dan Ponorogo dengan penambahan kompos trubus dapat meningkatkan rata-rata jumlah cabang dua kali lebih banyak, sedangkan pada aksesi Jember dan Bengkulu tidak mencapai dua kali. Namun untuk aksesi Sukabumi jumlah cabang yang terbentuk dengan penambahan kompos trubus sama dengan tanpa penambahan bahan organik.

Penambahan kotoran sapi meningkatkan jumlah cabang satu kali atau lebih dari satu kali banyaknya pada aksesi Madiun, Jember, Sukabumi dan Ponorogo bahkan untuk aksesi Bengkulu sampai dua kali banyaknya. Terdapat pola yang berbeda pada aksesi Lampung karena tanpa penambahan bahan organik jumlah cabang lebih banyak dari pada yang diberikan bahan organik tetapi cabangnya kecil-kecil.

Tabel 3 Jumlah cabang umur 8 BST

\begin{tabular}{cccccccc}
\hline $\begin{array}{l}\text { Bahan } \\
\text { organic }\end{array}$ & \multicolumn{7}{c}{ Jumlah cabang } \\
& AM & AP & AJ & AD & AL & AB & AS \\
\hline B0 & $2-3$ & $0-4$ & 0 & $2-4$ & 4 & $1-2$ & $2-4$ \\
B1 & $1-7$ & $2-7$ & $0-4$ & $2-3$ & $1-3$ & $2-4$ & $1-3$ \\
B2 & $2-4$ & $1-6$ & $0-3$ & $3-4$ & $2-4$ & $2-5$ & $2-5$ \\
\hline
\end{tabular}

Keterangan : AM:aksesi Madiun, AP:aksesi Ponorogo, AJ:aksesi Jember, AD:aksesi Dompu, AL:aksesi Lampung, AB:aksesi Bengkulu, AS:aksesi Sukabumi, B0:tanpa penambahan bahan organik, B1:penambahan kompos trubus, B2:penambahan kotoran sapi.

Pola pertambahan tinggi tanaman, diameter batang dan jumlah cabang tidak sama dengan pola berat kering tanaman total, berat kering tajuk, dan berat kering akar dalam pengelompokkan. Terdapat interaksi antara bahan organik dengan aksesi terhadap berat kering tanaman, berat kering tajuk, berat kering akar, dan nisbah tajuk akar (Tabel 4).

Pengaruh penambahan kompos trubus menunjukkan perbedaan yang sangat besar terhadap berat kering total tanaman, berat kering tajuk, dan berat kering akar dibandingkan dengan tanpa penambahan bahan organik. Berat kering total dikelompokkan dalam enam kelompok. Kelompok pertama aksesi Dompu selisih berat kering 104.1 gram; kelompok kedua aksesi Lampung selisih berat kering 202.1 gram; kelompok ketiga aksesi Ponorogo selisih berat kering 264.2 gram; kelompok keempat aksesi Bengkulu dan Madiun selisih berat kering 318.5 gram - 324.8 gram; kelompok kelima aksesi Sukabumi selisih berat kering 370.6 gram dan kelompok keenam aksesi Jember selisih berat kering 393.3 gram dibandingkan tanpa penambahan bahan organik.
Penambahan kompos untuk berat kering tajuk dikelompokkan dalam empat kelompok. Kelompok pertama aksesi Dompu selisih berat kering tajuk 61.2 gram; kelompok kedua aksesi Lampung selisih berat kering tajuk 113.9 gram; kelompok ketiga selisih berat kering tajuk antara 153 gram - 160.7 gram; sedangkan kelompok keempat aksesi Sukabumi selisih berat kering tajuk 189.2 gram dibandingkan dengan tanpa penambahan bahan organik. Sedangkan berat kering akar dikelompokkan dalam tujuh kelompok. Kelompok pertama aksesi Dompu selisih berat kering akar 42.8 gam; kelompok kedua aksesi Lampung selisih berat kerin akar 88.2 gram; kelompok ketiga aksesi Ponorogo selisih berat kering akar 109.9 gram; kelompok keempat aksesi Bengkulu selisih berat kering akar 159.8 gram; kelompok kelima aksesi Madiun selisih berat kering akar 171.8 gram; kelompok keenam aksesi Jember selisih berat kering akar 232.6 gram, dan kelompok ketujuh selisih berat kering akar 181.5 gram dibandingkan tanpa penambahan bahan organik.

Penambahan kotoran sapi terhadap berat kering total tanaman dikelompokkan dalam lima kelompok. Kelompok pertama aksesi Bengkulu selisih berat total tanaman 
215.2 gram; kelompok kedua aksesi Lampung selisih berat kering total tanaman 241.7 gram; kelompok ketiga aksesi Madiun dan Dompu selisih berat kering total tanaman 259.3 gram - 260.8 gram; kelompok keempat aksesi Sukabumi dan Ponorogo selisih berat kering total tanaman 282 gram - 285.4 gram sedangkan kelompok kelima aksesi Jember selisih berat kering total tanaman 737.4 gram dibandingkan tanpa penambahan bahan organik.

Penambahan kotoran sapi terhadap berat kering tajuk dikelompok dalam lima kelompok. Kelompok pertama aksesi Bengkulu selisih berat kering tajuk 110.7 gram; kelompok kedua aksesi Lampung selisih berat kering tajuk 134,9 gram; kelompok ketiga aksesi Dompu, Madiun, dan Sukabumi selisih berat kering tajuk 157.2 gram - 173.9 gram; kelompok keempat aksesi Ponorogo selisih berat kering tajuk 174.8 gram, dan kelompok kelima aksesi Jember selisih berat kering tajuk 272.7 gram dibandingkan tanpa penambahan bahan organik. Berat kering akar dikelompokkan dalam tiga kelompok. Kelompok pertama aksesi Madiun selisih berat kering akar 96 gram; kelompok kedua aksesi Dompu, Bengkulu, Lampung, Sukabumi, dan Ponorogo selisih berat kering antara 103.5 gram - 110.4 gram, dan kelompok keempat aksesi Jember selisih berat kering akar 465.5 gram dibandingkan tanpa penambahan bahan organik.

Nilai korelasi antara berat kering total tanaman dengan berat kering tajuk dan akar sebesar 0.96, berarti bahwa makin berat tanaman akan diikuti juga oleh meningkatnya berat tajuk dan akar. Hal ini juga menyatakan bahwa pola peningkatan berat kering tanaman sama dengan pola peningkatan berat kering tajuk dan akar.

Pola nisbah tajuk akar sangat bervariasi pada masing-masing aksesi jarak pagar baik yang diberikan kompos trubus maupun kotoran sapi. Aksesi Jember mempunyai nisbah tajuk akar yang paling rendah dibandingkan aksesi lain saat penambahan kompos trubus. Namun demikian, pada penambahan kotoran sapi pada aksesi Jember mempunyai nisbah tajuk akar paling rendah dibandingkan dengan penambahan kompos trubus.

Tabel 4 Berat kering tanaman, berat kering tajuk, berat kering akar, dan nisbah tajuk akar umur 8 BST

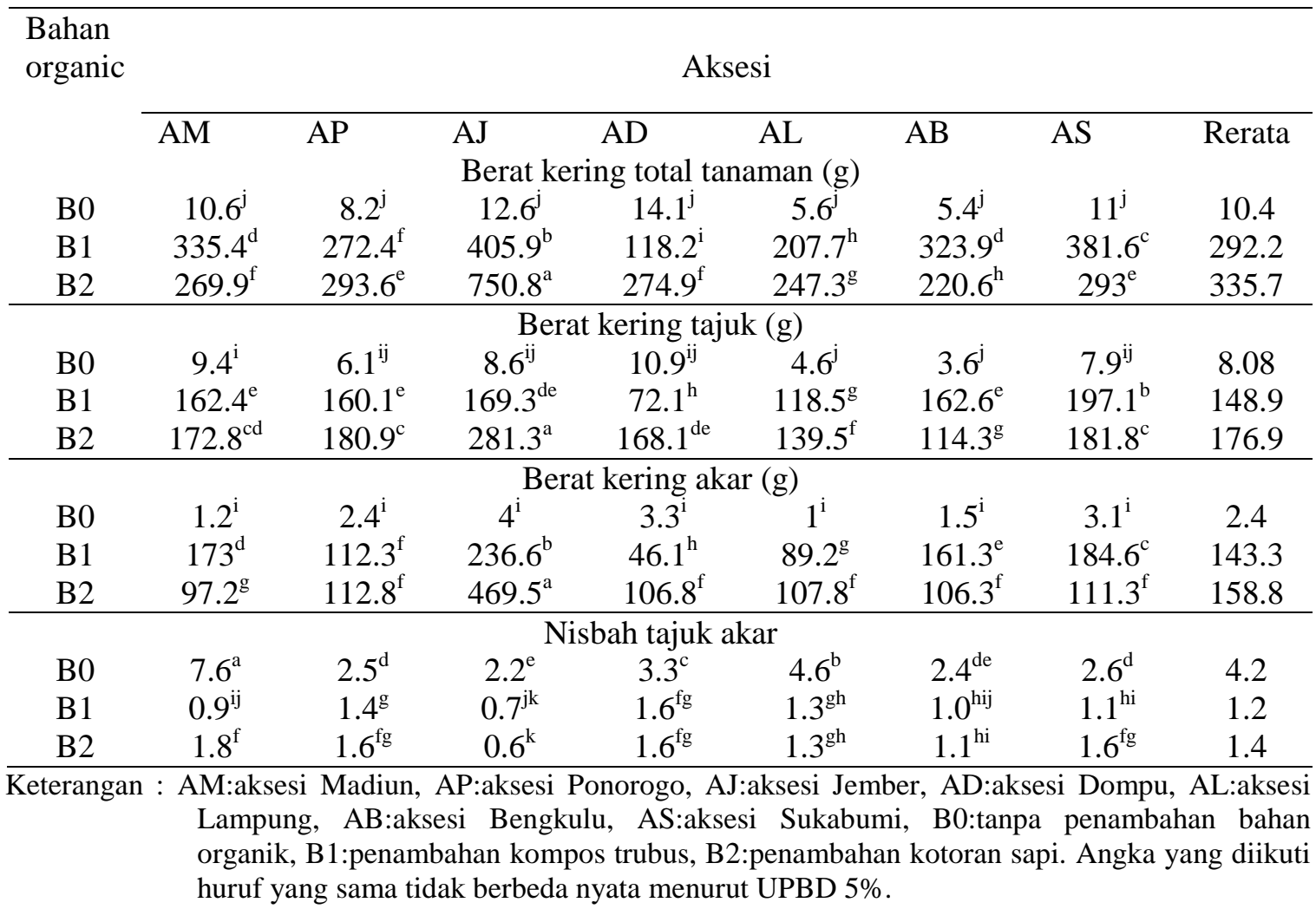


Tanaman yang tidak diberikan bahan organik mempunyai nisbah tajuk akar yang paling tinggi dibandingkan dengan yang diberikan bahan organik. Perkembangan akar akan dapat mengimbangi dan sekaligus mendukung pertumbuhan dan perkembangan tajuk yang baik. Perimbangan pertumbuhan tajuk terhadap akar dicerminkan oleh nilai nisbah tajuk-akar. Siagian et al. (1994) melaporkan bahwa semakin rendah nilai nisbah tajuk-akar pada bibit tanaman karet, semakin tahan bibit karet tersebut terhadap cekaman pasca pindah tanaman di lapangan. Semakin luas permukaan akar per satuan bobot kering akar, pasokan air bersama hara terlarut akan semakin baik sedangkan nisbah yang semakin kecil menandakan lebih rendahnya tajuk sehingga transpirasi yang terjadi juga lebih rendah dibandingkan dengan tanaman dengan nilai nisbah tajukakar lebih besar.

Untuk proses pertumbuhan dan perkembangan dan hasil tanaman membutuhkan nutrisi dari dalam tanah yang diserap oleh akar tanaman. Pada aksesi jarak pagar dan penambahan bahan organik berupa kompos trubus dan kotoran sapi tidak berpengaruh nyata terhadap serapan hara $\mathrm{N}$, $\mathrm{P}$, dan K. Pola serapan hara $\mathrm{N}$ untuk penambahan kompos trubus dan kotoran sapi tidak sama dengan pola serapan hara $\mathrm{P}$ dan $\mathrm{K}$. Pada Tabel 5 menunjukkan bahwa serapan hara $\mathrm{N}$ pada penambahan kompos trubus sama dengan penambahan kotoran sapi sedangkan pola serapan $\mathrm{P}$ dan $\mathrm{K}$ tidak sama yaitu penambahan kompos trubus meningkatkan nilai serapan $\mathrm{P}$ dan $\mathrm{K}$ lebih tinggi dari penambahan kotoran sapi.

Pola serapan $\mathrm{N}$ untuk aksesi dikelompokkan atas tiga bagian berdasarkan nilai serapan yang berdekatan nilainya yaitu kelompok pertama aksesi dengan serapan paling rendah aksesi Madiun, kelompok kedua dengan serapan yang lebih tinggi yaitu aksesi Ponorogo dan Lampung sedangkan kelompok yang ketiga dengan serapan tertinggi aksesi Jember, Dompu, Bengkulu dan Sukabumi. Pola untuk N berbeda dengan $\mathrm{P}$, pengelompokkan hanya atas dua bagian yaitu pertama aksesi Madiun, Jember, Lampung, Bengkulu dan Sukabumi dengan selang nilai serapan $0.31 \%-0.36 \%$ sedangkan kedua terdiri dari aksesi Ponorogo dan Dompu dengan nilai serapan $0.47 \%$ -
$0.48 \%$. Demikian juga terdapat pola yang berbeda pada serapan K. Pengelompokkan dibagi atas tiga bagian yaitu kelompok pertama aksesi Madiun dan Jember dengan serapan paling rendah, kemudian kelompok kedua aksesi Ponorogo, Dompu, Lampung dan Bengkulu dengan serapan yang lebih tinggi sedangkan kelompok ketiga aksesi Sukabumi dengan serapan K yang tertinggi.

Faktor aksesi jarak pagar dan penambahan bahan organik berupa kompos trubus dan kotoran sapi berpengaruh nyata terhadap hasil biji dan kandungan minyak serta terdapat interaksi antara kedua faktor tersebut (Tabel 6). Ternyata pola serapan hara tidak sama dengan pola berat biji dan kandungan minyak. Serapan hara $\mathrm{N}$ tertinggi pada aksesi Bengkulu tidak diikuti dengan tingginya hasil biji, tetapi serapan hara $\mathrm{P}$ tertinggi pada aksesi Dompu diikuti juga dengan tingginya hasil biji, sedangkan serapan $\mathrm{K}$ tertinggi pada aksesi Ponorogo tidak diikuti dengan hasil yang tinggi.

Respon penambahan kompos trubus pada aksesi jarak pagar terhadap hasil biji terdiri dari kelompok hasil biji yang terendah pada aksesi Madiun dan Ponorogo dengan hasil biji $15.1 \mathrm{~g}-17.4 \mathrm{~g}$ setiap tanaman, kelompok aksesi Jember dan Bengkulu dengan hasil biji 50.7 - 61.2 g setiap tanaman, kelompok aksesi Lampung dan Sukabumi dengan hasil biji $74.3 \mathrm{~g}-79.8 \mathrm{~g}$ setiap dan kelompok dengan hasil tertinggi yaitu aksesi Dompu sebesar 97.9 g setiap tanaman. Hasil biji pada penambahan kompos trubus berbeda pola dengan hasil biji pada penambahan kotoran sapi. Penambahan kotoran sapi terdapat tiga kelompok yaitu kelompok pertama yang terendah pada aksesi Madiun dan Ponorogo, kelompok kedua pada aksesi Jember dan Dompu sedangkan kelompok ketiga hasil tertinggi dengan kisaran $92 \mathrm{~g}$ - $99.4 \mathrm{~g}$ setiap tanaman pada aksesi Lampung, Bengkulu dan Sukabumi.

Rendahnya hasil biji yang didapatkan diduga disebabkan adanya kompetisi antara penggunaan fotosintat untuk pertumbuhan vegetatif dan untuk pembentukan buah. Pembentukan tandan buah yang akan menghasilkan biji sangat membutuhkan air, seperti yang dilaporkan oleh Pitono et al. (2008). Kondisi kering mengakibatkan proses pembentukan bunga terhambat dan 
menurunkan keberhasilan pembentukan buah jarak pagar.

Tabel 5 Serapan hara N, P, dan K umur 6 BST

\begin{tabular}{|c|c|c|c|c|c|c|c|c|}
\hline \multirow[t]{2}{*}{$\begin{array}{l}\text { Bahan } \\
\text { organic }\end{array}$} & \multicolumn{8}{|c|}{ Aksesi } \\
\hline & $\mathrm{AM}$ & AP & $\mathrm{AJ}$ & $\mathrm{AD}$ & $\mathrm{AL}$ & $\mathrm{AB}$ & AS & Rerata \\
\hline \multicolumn{9}{|c|}{ Serapan N (\%) } \\
\hline B0 & 1.01 & 1.31 & 1.23 & 2.75 & 1.00 & 1.65 & 1.49 & 1.29 \\
\hline B1 & 1.37 & 1.94 & 2.28 & 1.10 & 1.87 & 2.62 & 2.31 & 1.92 \\
\hline B2 & 1.85 & 1.70 & 2.29 & 1.98 & 1.89 & 1.64 & 2.11 & 1.92 \\
\hline Rerata & 1.41 & 1.65 & 1.93 & 1.94 & 1.58 & 1.97 & 1.97 & \\
\hline \multicolumn{9}{|c|}{ Serapan P (\%) } \\
\hline B0 & 0.11 & 0.20 & 0.10 & 0.34 & 0.21 & 0.28 & 0.52 & 0.25 \\
\hline B1 & 0.49 & 0.68 & 0.55 & 0.80 & 0.40 & 0.34 & 0.23 & 0.49 \\
\hline B2 & 0.36 & 0.57 & 0.30 & 0.29 & 0.38 & 0.48 & 0.43 & 0.40 \\
\hline Rerata & 0.32 & 0.48 & 0.31 & 0.47 & 0.33 & 0.36 & 0.39 & \\
\hline \multicolumn{9}{|c|}{ Serapan K (\%) } \\
\hline B0 & 0.15 & 0.14 & 0.21 & 1.42 & 0.41 & 0.80 & 1.16 & 0.61 \\
\hline B1 & 1.66 & 2.21 & 1.31 & 1.01 & 1.29 & 2.05 & 2.02 & 1.65 \\
\hline B2 & 0.66 & 0.96 & 1.00 & 1.56 & 1.94 & 0.92 & 1.36 & 1.20 \\
\hline Rerata & 0.82 & 1.10 & 0.84 & 1.33 & 1.21 & 1.25 & 1.51 & \\
\hline
\end{tabular}

Terdapat pola yang berbeda antara berat biji dengan kandungan minyak. Pada aksesi Madiun, Ponorogo, Lampung, Bengkulu dan Sukabumi mempunyai kandungan minyak lebih tinggi pada pemberian kompos trubus sedangkan aksesi Jember dan Dompu lebih tinggi kandungan minyak pada pemberian kotoran sapi.

Namun demikian kandungan minyak tertinggi pada aksesi Dompu. Terdapat nilai korelasi antara hasil biji dengan kandungan minyak sebesar 0.65 berarti bahwa kalau hasil biji meningkat akan meningkatkan kandungan minyak juga.

Tanaman jarak pagar menghasilkan biji yang memiliki kandungan minyak cukup tinggi yaitu sekitar 30-50\% (Hambali et al. 2006). Kandungan minyak jarak pagar bervariasi dari setiap aksesi yang ditanam yaitu berkisar antara 24.9-39.6\% (Tabel 6). Hasil pengujian kadar minyak yang dilakukan tidak berbeda jauh dengan hasil pengujian kadar minyak dari beberapa tempat dan aksesi. Kadar minyak dari beberapa tempat dan aksesi yaitu 10 aksesi dari India 33-39\% (Ginwal et al., 2004); 6 pohon dari India diekstrak dari kernel 23-45\% (Pant et al., 2006); 23 aksesi dari India 26-35\% (Patolia et al., 2007); provenan dari India 29-39\% (Sharma, 2007); 24 aksesi dari India 28-39\% (Kaushik et al., 2007) dan 20 genotipe yang berasal dari Indonesia 39-43\% (Hartati et al., 2009). Berdasarkan hasil di atas bahwa kadar minyak biji dipengaruhi oleh genotipe jarak pagar dan lingkungan. 
Tabel 6 Produksi biji (g) dan kandungan minyak (\%)

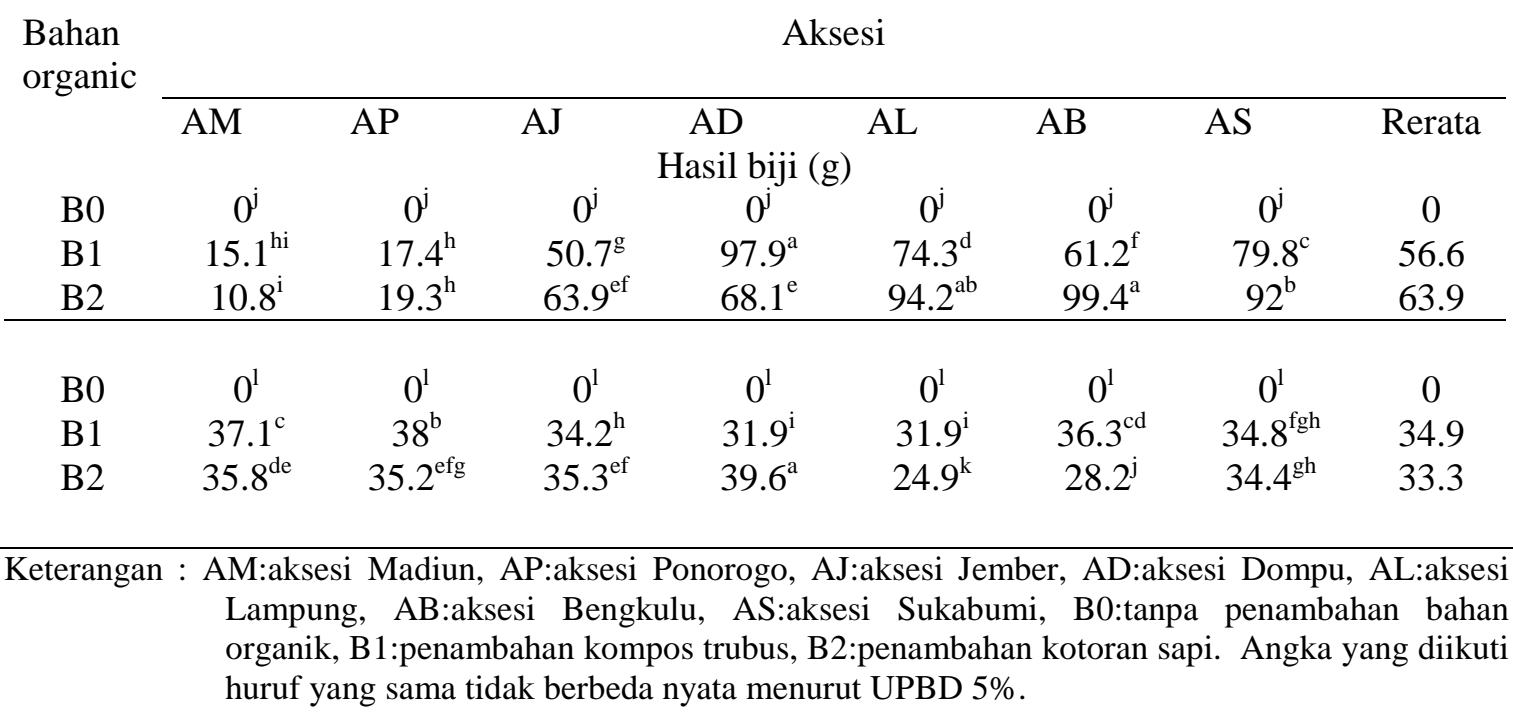

\section{KESIMPULAN}

Pertumbuhan awal yang paling baik untuk tanah bekas tambang timah adalah aksesi Jember berupa diameter batang, berat kering tanaman, berat kering tajuk dan berat kering akar, sedangkan untuk tinggi tanaman tertinggi pada aksesi Madiun.

Tanah bekas tambang timah dapat diperbaiki kesuburannya dengan memberikan kompos dan kotoran sapi. Penambahan kotoran sapi dapat meningkatkan produksi biji jarak pagar yang paling tinggi pada aksesi Bengkulu dan kandungan minyak tertinggi pada aksesi Dompu.

\section{DAFTAR PUSTAKA}

Amriwansyah. 1990. Evaluasi dan Deskripsi Beberapa Sifat Fisik dan Kimia Tanah Sebelum (Kondisi Tanah Alami) dan Setelah (Kondisi Tanah Kolong) Proses Aktivitas Penambangan Timah di Tiga Lokasi Unit Penambangan Timah Bangka (Tambang 23, 25 dan 45) Wilayah Produksi Pulau BangkaSumatera Selatan. [Skripsi] Jurusan Tanah Fakultas Pertanian-Institut Pertanian Bogor. Bogor.
[AOAC] Association of Official Analytical Chemist. 1990. Official Methods of Analysis (15 th. Ed). Arlington : Association of Official Analytical Chemist.

[BPS] Badan Pusat Statistik Kabupaten Bangka. 2001. Bangka dalam Angka 2000. Badan Pusat Statistika Kabupaten Bangka dan Badan Perencanaan Pembangunan Daerah Kabupaten Bangka. Sungai Liat. Bangka.

Ginwal HS, Rawat PS, Srivastava RL. 2004. Seed source variation in growth performance and oil yield of Jatropha curcas L. in Central India. Silvae Genet. 53(186-192).

Hartati RRS, Setiawan A, Helianto B, Pranowo D, Sudarsono. 2009. Keragaan morfologi dan hasil 60 individu jarak pagar (Jatropha curcas L.) terpilih di kebun percobaan Pakuwon Sukabumi. J Littri15:152161.

Hasnam dan Z. Mahmud. 2006. Panduan Umum Perbenihan Jarak Pagar (Jatropha curcas L.). Pusat Penelitian dan Pengembangan Perkebunan, Penelitian dan Pengembangan Pertanian. Departemen Pertanian. Edisi 2. Bogor : Deptan. 
Kaushik N, Kumar K, Kumar S, Kaushik N, Roy S. 2007. Genetic variability and divergence studies in seed traits and oil content of Jatropha (Jatropha curcas L.) accessions. Biomass and Bioenergy 31(497-502)

Leon AJ, Andrade FH, Lee M. 2003. Genetic Analysis of Seed-Oil Concentration Across Generation and Environments in SunFlower. Crop Sci. 43:135-140.

Pant KS, Khosla V, Kumar D, Gairola S. 2006. Seed oil content variation in Jatropha curcas Linn. in different altitudinal ranges and site conditions in H.P. India. Lyonia 11(31-34)

Patolia JS, Chikara J, Prakash AR, Ghosh A, Chaudharry DR, Bhuva HM. 2007. Provenance trials for selection of high yielding Jatropha curcas on wastelands. Expert seminar on Jatropha curcas L. Agronomy and genetics. 26-28 March 2007, Wageningen, the Netherlands, Published by FACT Foundation.

PT. Tambang Timah (Persero). 1991. Studi Evaluasi Lingkungan Unit Penambangan dan Unit Peleburan Timah Pulau Bangka. Ringkasan Eksekutif Volume 1-4. PT. Tambang Timah. Pangkal Pinang.
Sharma N. 2007. Effect on germination on raised bed and sunken bed nursery in different provenances of Jatropha curcas L. Expert seminar on Jatropha curcas L. Agronomy and genetics. 2628 March 2007, Wageningen, the Netherlands, Published by FACT Foundation.

Siagian, Sutardi, Indraty IS. 1994. Umur bibit dan daya adaptasi pasca penanaman bibit karet (Hevea braziliensis). Risalah Penelitian. Research Centre Getas, Salatiga. 18:12-18.

Sitorus SRP, Kusumastuti E, Badri LN. 2008. Karakteristik dan teknik rehabilitasi lahan pasca penambangan timah di pulau Bangka dan Sinekep. $J$ Tanah dan Iklim 27:57-74.

Sujitno S. 2007. Sejarah Penambangan Timah Di Indonesia Abad Ke18 Abad Ke 20. Pangkalpinang : PT. Timah (Tbk). 